\title{
The Passing of Eden: Pomona, California Catherine Davis
}

\author{
To Glen Epstein
}

There are foxes on this hill, friend, and rattlesnakes. But deer also wander dreamily among the palms, persimmons, and cypresses and appear at Kellogg mansion to browse on the lawn and even come down at night when no one's near to the dreamless beds below where, filling the night air, bloom roses on roses, all year long, but which, for some time past, thieves, or perhaps vandals, not prizing the long stems - from mere meanness was the common view have been ripping off. I read today it's becoming clear who the culprits are. But oh the deer-I saw one close by but fugitive, without peer for remoteness-know nothing of the passing of Eden or the price of roses here. Still, whenever I linger absently in the garden now, I wonder, will I hear the whispers of hooves, as light as sighs, among the roses? What can we do when the deer, half-visions all day, steal down at night from the hill and eat the roses and disappear? 